\title{
Comparative Analysis of Water Samples from Three Different Sources (A Case Study of Bosso, Minna Niger State)
}

\author{
Musa, J. J ${ }^{1}$, Adejumo, B. A ${ }^{1}$, And Fumen, G. A ${ }^{2}$. \\ 1. Department of Agricultural \& Bioresources Engineering Federal University of Technology, P M B 65, \\ Minna, Nigeria \\ 2. Samaru College of Agriculture, Ahmadu Bello University, Zaria, Nigeria
}

\begin{abstract}
This study assesses the level of potability of water samples harvested from different sources roof in Bosso LGA in Niger state, Nigeria. To achieve this goal a physiochemical analysis was carried out on three water samples collected from galvanized iron roofing sheets, a well and a borehole. The harvested water samples were analyzed for major physical and chemical quality parameters as recommended by World Health Organization (WHO) and Nigerian Standard for Drinking Water Quality (NSDWQ) and results compared. The results showed for $\mathrm{pH}$ (7.2, 6.6 and 7.5), alkalinity (48.7, 52, and 81.1), electrical conductivity (176, 104, and 230), total dissolved solids (88, 52, and 115), total hardness (55, 39, and 93), colour (4.0, 8.4, and 3.3), Temperature (23.2, 23.2, and 23.2), Zn (6, 4 and -), sulphate (0.9, 29, and 26), turbidity (2.1, 6.7 and 1.8), iron $(0.14,0.21$, and 0.03) and TSS (0, 2.8 and 0$)$ for galvanized iron roof sheet, well and borehole respectively. Some of the results observed met the recommended standards for drinking. Thus, rainwater from these rural settlements can be harvested and stored domestic purpose. Similarly, significant differences exist amongst the water samples collected from the three sources. Thus, rainwater from these sources should be purified before consumption.
\end{abstract}

Keywords: Borehole, domestic, physicochemical properties, rain, well

\section{Introduction}

Man realized from the very beginning that water is about the most essential element for satisfaction of all his basic needs (Geetha, et. al., 2008). Water is the essence of life and safe drinking water is a basic human right essential to all. It is essential for the wellbeing of mankind and for sustainable development. Though, necessary for human survival, many are denied access to sufficient potable drinking water supply and sufficient water to maintain basic hygiene. The effects of drinking contaminated water results in thousands of deaths every day, mostly in children under five years in developing countries. Thus, access to safe clean water and adequate sanitation is a fundamental right and a condition for basic health. The use of shallow ground water sources for drinking and other domestic purposes is a common feature for many low income communities in developing countries (Musa and Ahanonu, 2013).

Ground water which occurs beneath the earth surface is considered free from contamination, hence usable but anthropogenic as well as natural factors are affecting the quality as well as quantity of this valuable resource. It has been estimated that once pollution enters the subsurface environment, it may remain concealed for many years, becoming dispersed over wide areas of groundwater aquifer and rendering groundwater supplies unsuitable for consumption and other uses. Therefore, understanding the potential influences of human activity on ground water quality is important for protection and sustainable use of ground water resources (Jehangir, et. al., 2011). Shallow wells are normally located in the valleys where the groundwater table is relatively high (1$4 \mathrm{~m}$ below ground level) and infiltration of rain and river water plays a main part in groundwater recharge (Pritchard et al., 2008).

Roof-top harvesting systems are most commonly used as the quality of harvested water is reasonably good if the harvesting procedure is coupled with proper installation and maintenance (Thomas and Martinson 2007). The quantity and quality of rainwater harvested depends on the rain intensity, the roof's surface area, the type of roofing material and the surrounding environment (Luke, 2005). It is generally believed that roof runoffs are significantly cleaner than other storm water sources. This may not be generally true as roofs have a potential to release dissolved and particulate metals such as lead, copper, zinc and total metals generally into collected water. Roof-top harvesting systems are most commonly used as the quality of harvested water is reasonably good if the harvesting procedure is coupled with proper installation and maintenance. It is generally believed that roof runoffs are significantly cleaner than other storm water sources (Bada, et. al., 2012).

Roofs are made of a variety of materials which can be potential sources of dissolved ions, alkalinity and trace metals. Asbestos sheets (Slates), painted or coated galvanized iron (Pan) and anodized aluminum are most 
commonly used as roofing sheets in Nigeria. With the health risks associated with asbestos as well as the possibility of leaching from roofing sheets, there is need to investigate physical and chemical properties of water harvested from the various roofing sheets commonly used in Nigeria (Bada, et. al., 2012).

Water contamination containing toxic substances are generated by a wide variety of chemical processes, as well as by a number of other common household and agricultural applications. In this context, galvanized roofing sheets and their chemicals are toxic recalcitrant compounds, which may accumulate in the environment. The inadequate management of these effluents can have harmful consequences to human health.

Pure water has different connotations to individuals in various fields. The bacteriologist, for example, is apt to regard pure water as a sterile liquid, that is, one with no living bacteria in it. The chemist, on the other hand, classifies water as pure when it possesses no mineral, gaseous or organic impurities. It is obvious that pure water as described is likely to be found only in laboratories and even there only under ideal conditions.

The objective of this study is to analyze the quality of water collected from galvanized roofing sheets, well and borehole and compared the results with World Health Organization (WHO, 2004) and Nigerian Standard for Drinking Water Quality (NSDWQ, 2007).

\section{Methodology}

Niger State with Minna as the State capital is located in the middle belt zone of the north central area of Nigeria. The State is also known for its agricultural activities. Bosso village, a minimally populated community in Bosso Local Government Area of Niger State, it lies in the savanna zone of the tropics between latitude $\left(8^{0} 10^{1} \mathrm{~N}\right.$ and $\left.11^{0} 30^{1} \mathrm{~N}\right)$ and longitude $\left(3^{0} 30^{1} \mathrm{E}\right.$ and $\left.7^{0} 30^{1} \mathrm{E}\right)$. Figure 1 below shows the location of Bosso community in the map of Minna.

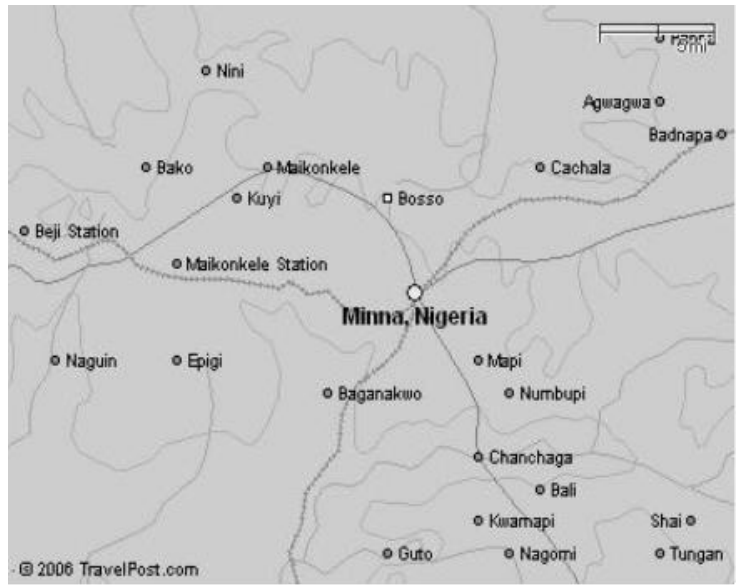

Figure 1: Map of Minna showing the exact location of Bosso

The type of roofing materials that are commonly used in Bosso local Government Area, Niger state for rainwater harvesting were identified to be galvanized metal sheets as this is the most common type of roofing material used in construction works.

The plastic containers to be used to collect samples were thoroughly washed and rinsed three times with the samples before the actual samples were collected. The samples were collected in a $2 \mathrm{~L}$ plastic bottle and acidified with nitric acid (HNO) to maintain a steady state of $\mathrm{pH}$. Plastic containers were used to prevent sample contamination from metallic containers. The same process was used for the collection of the well and borehole water. The samples for trace metal determination and other parameters were preserved in an iced box at a temperature of $4{ }^{\circ} \mathrm{C}$ to allow the samples maintain its natural state during the cause of transportation the laboratory. This follows the standards specified in the works of Musa, et al., (2011). Ten water samples from the selected sites were collected.

To identify and locate samples easily, all samples carried were carefully labeled. The information carried on the sample label includes location, date and time of collection. Standard procedures as stated by (AOAC, 1990) were followed to determine various parameters (physical, inorganic and organic) of the samples collected. The physical parameters determined are $\mathrm{pH}$, electrical conductivity, turbidity, total dissolved solids, total suspended solids, total hardness, calcium hardness and total alkalinity. The inorganic parameters determined are chloride ion, phosphate ion, sulphate ion, nitrates and trace metals. The organic parameters determined included are Biological Oxygen Demand (BOD), Chemical Oxygen Demand (COD), Total Organic Carbon (TOC) and Theoretical Oxygen Demand (TOD). 


\section{Results and Discussion}

The average results of the physiochemical analysis carried out on the various water samples (galvanized rooftops, borehole and shallow well) and the national (NSWDQ, 2007) and international standard (WHO, 2006) for drinking water are presented in Table 1.

Table 1: Results of averaged Physiochemical Analysis of Water samples compared with the national and international standards

\begin{tabular}{lllllll}
\hline S/N & PARAMETERS & $\begin{array}{l}\text { Galvanized } \\
\text { roof }\end{array}$ & Well & Borehole & WHO & NSWDQ \\
\hline 1 & Electrical conductivity (us/cm) & 176.0 & 104 & 230 & 1200 & 1000 \\
2 & Total dissolved solid (mg/L) & 88.0 & 52.0 & 115 & 1000 & 500 \\
& & 23.2 & 23.2 & 23.2 & $25(\mathrm{amb})$ & 25 \\
3 & Temperature (0C) & 0.0 & 2.8 & 0 & 400 & 500 \\
4 & Suspended solids (mg/L) & 2.1 & 6.7 & 1.8 & 0.1 & 0.1 \\
5 & Turbidity (NTU) & 4.0 & 8.4 & 3.3 & 15 & N/S \\
6 & Colour (Pt. Co) & 7.2 & 6.6 & 7.5 & 6.5 to 8.5 & 6.5 \\
& & 0.14 & 0.21 & 0.03 & 0.3 & to \\
7 & pH & 0.9 & 29.0 & 26 & 450 & 500 \\
8 & Iron & 6.1 & 5.2 & 4.7 & N/A & N/A \\
9 & Sulphate (mg/L) & 28.0 & 24.1 & 23.1 & 50 & 10 \\
10 & Nitrate as Nitrogen (mg/L) & 55.0 & 39.0 & 93 & 200 & 150 \\
11 & Nitrate (mg/L) & 22.1 & 16.3 & 38.8 & 500 & N/A \\
12 & Total hardness (mg/L) & 34.5 & 25.0 & 58.3 & 200 & N/A \\
13 & Hardness (ca) as caco3 & 48.7 & 52.0 & 81.1 & 100 & N/A \\
14 & Hardness (mg/L) & 6.0 & 4.0 & - & 3 & 3 \\
15 & Total Alkalinity (mg/L) & & & & & \\
16 & Zinc (mg/L) & & & & & \\
\hline
\end{tabular}

Electrical Conductivity (EC), also called specific conductance, is a measure of ability of water sample to convey an electric current and it is related to the concentration of ionized substance in water. The EC values were 176, 104, and 230 for galvanized rooftop rainwater, shallow well and borehole samples respectively. These values, when compared to the guidelines were below the $1000 \mu \mathrm{S} / \mathrm{cm}$ WHO (2004) and NSWDQ (2007) limits. It therefore poses no salinity problem and there is no restriction on the use of the water for consumption. Conductivity can be used as an approximate measure of the total concentration of inorganic substances in water.

Total Dissolved Solids of the samples were 88, 52, and 115 for galvanized rooftop rainwater, shallow well and borehole samples respectively. When compared with the guidelines of WHO (2004) and NSDWQ (2007), it was observed that the values for the three samples were below the WHO and NSDWQ limits. Hence the water does not pose any threat for use for domestic purpose. This is in conformity with the works of Adeoye and Musa (2012).

The temperature of water is an important parameter because of its effect on chemical reactions, reaction rates, and aquatic life. The temperatures for galvanized rooftop rainwater, shallow well and borehole samples were $23.2{ }^{\circ} \mathrm{C}$, which is lower than the WHO (2004) and NSDWQ (2007) limits. Therefore the water temperature will not cause harm to aquatic life and other beneficial uses. Optimal temperatures for bacterial activity are in range from 25 to $35^{\circ} \mathrm{C}$.

Suspended solids for galvanized rooftop rainwater, shallow well and borehole samples were $0,2.8$ and $0 \mathrm{mg} / \mathrm{L}$ respectively. It was observed that the suspended solids for both galvanized rooftop rainwater and borehole were found to be 0 while that of sample B was seen to be present as 2.8. This may be due to the fact the galvanized rooftop water sample was not collected at the beginning of the rainy season as most of the dirty part of the rooftops had been washed off before the collection of the sample while that of the borehole may be as a result of the depth of the borehole which gives room for the screening process that takes place through the soils. The values of the samples were found to be relatively low when compared with the standards of WHO (2004) and NSDWQ (2007) thus allowing for the use of these water samples for domestic and industrial purpose.

Turbidity is the degree to which water loses its transparency due to the presence of suspended particulates. Turbidity values obtained were 2.1, 6.7 and 1.8 NTU for galvanized rooftop rainwater, shallow well and borehole samples respectively. From the result obtained, the turbidity level were found to be above the WHO 
(2004) and NSDWQ (2007) recommendations which poses threats of absorbing heat from the sunlight, making turbid waters becomes wormer, and thus reducing the concentration of oxygen in the water.

The colour of the samples ranged between 3.3 and 8.4 Pt.Co. It was observed that the values were below the recommended value of WHO (2004) while NSDWQ (2007) had no recommended value. Therefore by this, the WHO standard clears the various water samples for domestic use.

$\mathrm{pH}$ is a measure of the acidity or alkalinity of the water. The $\mathrm{pH}$ obtained was 7.2, 6.6 and 7.5 for galvanized rooftop rainwater, shallow well and borehole samples respectively. In general, water with $\mathrm{pH}<7$ is considered acidic and with a $\mathrm{pH}>7$ is considered alkaline or basic. Most of the waters are slightly alkaline due to presence of carbonates and bicarbonates. The normal pH value recommended by WHO (2004) and NSDWQ (2007) ranges between 6.5 and 8.5. The various samples of water are therefore recommended for drinking and other domestic uses.

Iron content obtained was $0.14,0.21$, and 0.03 for galvanized rooftop rainwater, shallow well and borehole samples respectively. When these values were compared to the guidelines of WHO (2004) and NSDWQ (2007), the values were found to be below $0.3 \mathrm{mg} / \mathrm{L}$ limits. Despite being the second most abundant element on earth's crust, iron is present in relatively small amount in natural waters. High concentration of iron is not known to have any adverse health effects; however they may lead to other problem.

Sulphate $\left(\mathrm{SO}_{4}{ }^{2-}\right)$ is a major ion occurring in water, the main natural source of sulphate in surface and ground water is the processes of chemical weathering and dissolution of sulphur-containing minerals, predominantly gypsum $\left(\mathrm{CaSO}_{4} .2 \mathrm{H}_{2} \mathrm{O}\right)$. Other natural sources are the oxidation of sulfides and elemental sulfur, and the decomposition of animal and plant residues. Sulphate values obtained were 0.9, 29, and 26 for galvanized rooftop rainwater, shallow well and borehole samples respectively; it was observed that the values obtained were very low compared to guideline of WHO (2004) and NSDWQ (2007) of 200mg/L limits thus allowing its safe usage for domestic and industrial purposes.

The presence of nitrate ions in unpolluted surface water is due mainly to the natural purifying processes such as nitrification. The nitrate content of drinking water is increasing at an alarming rate in both developed and developing countries owing largely to lack of proper sewage treatment, and excessive fertilizer application to agricultural farmlands. The nitrate content for galvanized rooftop rainwater, shallow well and borehole samples ranges between 28.0, 24.1 and $23.1 \mathrm{mg} / \mathrm{L}$ respectively while nitrate as nitrogen ranges between 6.1 , 5.2 and $4.7 \mathrm{mg} / \mathrm{L}$ respectively.

The WHO (2004) drinking water guideline is $50 \mathrm{mg} / \mathrm{L}$ while that of NSDWQ (2007) was not stated. It was observed that the nitrate values were within the range of the WHO recommendation which further implies that no adverse effect was observed with water concentration of $<30 \mathrm{mg} / \mathrm{L}$, expect for mathaemoglobinemia in infants. Nitrate in drinking water is a major health concern because of its toxicity, especially to young children. While for nitrates as nitrogen in the water samples no specified guidelines where given by WHO (2004) and NSDWQ (2007).

The hardness of water is characterized by its ability to form lather with soap. Total hardness is defined as the sum of Calcium (Ca) and Magnesium ( $\mathrm{Mg}$ ) concentrations expressed as calcium carbonate in $\mathrm{mg} / \mathrm{L}$ or $\mathrm{ppm}$. Hardness $(\mathrm{Ca})$ is due to magnesium in the water only. Total hardness of $(\mathrm{Ca}$ and $\mathrm{Mg}$ ) values obtained was $22.1,16.3$ and $38.8 \mathrm{mg} / \mathrm{L}$ while total hardness $34.5,25.0$ and $58.3 \mathrm{mg} / \mathrm{L}$ for galvanized rooftop rainwater, shallow well and borehole samples respectively. The values obtained from the total hardness do not exceed WHO (2004) and NSDWQ (2007) limits therefore it is good for consumption. It was observed that the value obtained for the hardness of the samples was found to be within the range of the stated guideline by WHO (2004) while NSDWQ (2007) had no guideline stated.

Total alkalinity is the total concentration of bases in water expressed as parts per million (ppm) or milligrams per liter $(\mathrm{mg} / \mathrm{l})$ of calcium carbonate $\left(\mathrm{CaCO}_{3}\right)$. Total alkalinity values obtained are as follows $48.7,52$, and 81.1 for galvanized rooftop rainwater, shallow well and borehole samples respectively. Water with high total alkalinity is not always hard, since the carbonates can be brought into the water in the form of sodium or potassium carbonate. An important environmental aspect of alkalinity in natural water is the capacity to neutralize acidity originating from atmospheric decomposition. Although alkalinity has a little public health significance, highly alkaline waters are unpalatable and are not used for domestic water supply. When the values obtained were compared with the WHO (2004) and NSDWQ (2007), it was observed that the values were below the acceptable limits.

Zinc content obtained was 6, 4, and 0 for galvanized rooftop rainwater, shallow well and borehole samples respectively; these values when compared to the guidelines, it was noticed that sample from galvanized iron roof and well sample were found above $3.0 \mathrm{mg} / \mathrm{L}$ WHO (2004) and NSDWQ (2007) limits. 


\section{Conclusion}

The results from the physiochemical analysis of water samples collected from galvanized rooftop, borehole and well shows that the water is pure and wholesomely free from high concentration of contaminants and can be used for drinking, domestic or agricultural purpose. This can be observed from the comparism between the obtained values from the laboratory and the various international and national standards. However, rainwater was of higher quality than water supplied by a water utility, borehole and shallow well water. High zinc concentration in the roof water was attributed to the galvanized iron sheets used for roofing and rain guttering.

It is therefore possible to harvest rainwater that could meet the WHO guidelines as long as materials used to construct rain water harvest systems were carefully selected to avoid contamination of the rainwater. Simple disinfection methods such as boiling and chlorination are recommended if water is to be used for drinking purposes.

\section{References}

[1]. Adeoye, A, P. and Musa, J. J., (2012): Appraisal of rural water supply for food security: Case study of Kwara State, north central Nigeria. $3^{\text {rd }}$ national Water Conference. Pp. 246-255

[2]. Association of Official Analytical Chemists (AOAC) (1990): AOAC Official Method of Analysis, 15 ${ }^{\text {th }}$ Edition, Association of Official Analytical Chemists, Washington DC.

[3]. Bada, B. S., Olatunde, K. A. and Bankole, O. D. (2012): Chemical and Physical Properties of Harvested Rainwater from Different Roofing Sheets in Abeokuta, Ogun State. Special Publication of the Nigerian Association of Hydrological Sciences, pp. 173-179

[4]. Geetha .A, Palanisamy P. N, Sivakumar .P, Ganesh K. P. and Sujatha .M. (2008): Assessment of Underground Water Contamination and Effect of Textile Effluents on Noyyal River Basin In and Around Tiruppur Town, Tamilnadu. E-Journal of Chemistry

[5]. Jehangir, A., Tanveer, A., Yousuf, A. R., Masood, A., and Naqash, A. H., (2011): Geochemistry and Irrigation Quality of Groundwater along River Jhelum in South Kashmir, India. Recent Research in Science and Technology 3(6): 57-63

[6]. Luke, M. (2005): Water Quality of Rainwater Harvesting Systems SOPAC Miscellaneous Report 579 pp. $4-6$.

[7]. Musa, J. J., and Ahanonu, J. J. (2013): Quality Assessment of Shallow Groundwater in Some Selected Agrarian Communities in Patigi Local Government Area, Nigeria. International Journal of Basic and Applied Science, Vol. 01, No. 03, Jan 2013, pp. 548-563

[8]. Musa, J J; Ode, O G; Anijofor, S C; and Adewumi; J K (2011): Quality Evaluation of Household Wastewater for Irrigation. J. Appl. Sci. Environ. Manage. Vol. 15 (3) $431-437$

[9]. Nigerian Standard for Drinking Water Quality (NSDWQ) (2007). Nigerian Industrial Standard. NIS 554: 2007 ICS 13.060.20

[10]. Pritchard, M., Mkandawire, T., and O’Neil, J. G., (2008): Assessment of groundwater quality in shallow wells within the southern districts of Malawi. Physics and Chemistry of the Earth 33: 812-823.

[11]. Thomas, T.H. and Martinson, D.B. (2007): Roof water Harvesting: A Handbook for Practitioners. Delft, the Netherlands, IRC International Water and Sanitation Centre. (Technical Paper Series; No. 49). 160 P. Pp 9, 15, 38, 99-108.

[12]. WHO, (2004): Rolling revision of the WHO guidelines for drinking-water quality, Draft for review and comments. Nitrates and Nitrites in drinking-water, World Health Organization (WHO/SDE/WSH/04.08/56). 